\title{
Tagetes minuta Propagation and Interaction With Nematoide
}

\author{
Camila T. Stroze ${ }^{1}$, Fernando C. Baida ${ }^{1}$, Maria I. Balbi-Peña ${ }^{1}$, Cláudia R. Dias-Arieira ${ }^{2} \&$ Débora C. Santiago $^{1}$ \\ ${ }^{1}$ Postgraduate Program in Agronomy, Londrina State University, University Campus, Londrina, PR, Brazil \\ 2 Postgraduate Program in Agrarian Sciences, Maringá State University, Umuarama Regional Campus, \\ Umuarama, PR, Brazil \\ Correspondence: Débora C. Santiago, Postgraduate Program in Agronomy, Londrina State University, University \\ Campus, Londrina, PR, Brazil. Tel: 55-439-9926-8756. E-mail: santiago@uel.br
}

Received: February 7, 2018

Accepted: July 1, 2018 Online Published: December 15, 2018

doi:10.5539/jas.v11n1p139

URL: https://doi.org/10.5539/jas.v11n1p139

\begin{abstract}
Tagetes minuta is a plant presenting pest and disease control potential, although its activity on some plant parasite nematode species is poorly investigated. The aim of the current study is to evaluate the best $T$. minuta propagation way, as well as the plant reaction to nematodes such as Heterodera glycines, Meloidogyne incognita and Pratylenchus brachyurus, through nematode penetration and reproduction studies and root morphological assessments. Seedlings obtained from woody cuttings showed larger rooting and stem diameter. Heterodera glycines penetration was higher than that recorded for M. incognita. However, both species recorded reproduction factor (RF) lower than one, as well as maximum RF values 0.34 and 0.02 for $H$. glycines and M. incognita, respectively. The highest FR recorded for T. minuta were found in P. brachyurus $(0.96$ and 0.80$)$ in the $60^{\text {th }}$ and $80^{\text {th }}$ day after inoculation (DAI). Root anatomy changes were observed in the $80^{\text {th }} \mathrm{DAI}$ in plants inoculated with $P$. brachyurus. Tagetes minuta was resistant to all nematodes; however, it did not prevent $P$. brachyurus activity in its roots.
\end{abstract}

Keywords: antagonistic plants, marigold, nematicide compounds, parasitism, phytonematodes

\section{Introduction}

Genus Tagetes belongs to family Asteraceae andcomprises more than 50 species; the most common ones are $T$. erecta L., T. patula L. and T. minuta L. (Soule, 1996). The species $T$. minuta is native to temperate regions; it is mainly found in Southern South America and in several regions in Europe, Africa and Asia (Naqinzhad \& Mehrvarz, 2007). It is an annual plant (50 to $150 \mathrm{~cm}$ tall), which has toxic flowers and particular smell, besides being considered a weed of early-winter dormancy in Brazil (Sadia et al., 2013). The species reproduction happens through seeds and each plant produces more than 29,000 seeds throughout the life cycle (Chamorro et al., 2012). However, similar to what happens to other weeds, T. minuta seeds show staggered germination (Felippe \& Pollo, 1983). This plant produces secondary metabolites such as monoterpenes, sesquiterpenes, flavonoids and thiophenols, which are responsible for the bioactivity exerted on different organisms (García et al., 2009; Hooks et al., 2010), besides presenting promising results in the control of insects of interest to public health and agricultural importance (Furtado et al., 2005; Tomova et al., 2005; Obongoya et al., 2010).

Despite the toxic potential of $T$. minuta, studies aimed at assessing the species performance in phytonematode control remain scarce, unlike what happens with other species, such as T. patula and T. erecta, whose nematode management efficiency was already confirmed (Natarajan et al., 2006; Marahatta et al., 2012; Moreira \& Ferreira, 2015). However, the intercropping between T. minuta and vegetables reduced Meloidogyne incognita (Kofoid \& White) Chitwood multiplication in tomatoes and eggplants, as well as Rotylenchulus reniformis Linford \& Oliveira and Tylenchorhynchus brassicae Siddiqi multiplication in tomatoes, eggplants, cabbages and cauliflowers (Siddiqui \& Alam, 1988). In addition, z- $\beta$-ocimene and dihydrotagetone oils extracted from $T$. minuta plants led to M. incognita egg mortality (Adekunle et al., 2007). In light of the foregoing, the aim of the current study was to evaluate the best way to obtain $T$. minuta seedlings, as well as to assess the plant reaction to and interaction with nematodes such as Heterodera glycines (Ichinohe), M. incognita and Pratylenchus brachyurus (Godfrey) Filipjev \& Sch. Stekhoven. 


\section{Materials and Methods}

The T. minuta plants used in the current study were collected in March 2016 from spontaneous vegetation (at

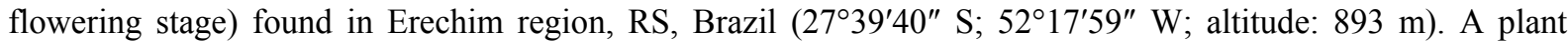
exsicata was prepared and sent to the Herbarium of the Botany Department at Londrina State University (Universidade Estadual de Londrina) for taxonomic identification and archiving purposes. Three ways of obtaining T. minuta seedlings were initially evaluated, namely: woody cuttings, obtained from branches $(5$ to $6 \mathrm{~cm}$ tall), herbaceous cuttings ( 2.5 to $3.5 \mathrm{~cm}$ tall), and seeds, obtained during the initial plant collection. The experiment was carried out in greenhouse; it followed a completely randomized design, with 64 repetitions per treatment.

The cuttings were removed from parent plants and bevel cuts were made in the branches, thus leaving two leaves per cutting. Next, cuttings and seeds were deposited in polystyrene trays containing a mixture composed of commercial BioPlant ${ }^{\mathbb{B}}$, vermiculite and sand substrate $(2: 1: 1)$, which was previously autoclaved at $120^{\circ} \mathrm{C}$, for 2 hours. The number of rooted cuttings and germinated seeds, as well as stem diameter and root length, were assessed 30 days later. Plants presenting root length longer than or equal to $1.0 \mathrm{~cm}$ were considered rooted. Subsequently, the susceptibility of $T$. minuta to three different phytonematodes was investigated. In order to do so, pure populations of $H$. glycines, M. incognita and P. brachyurus were multiplied in soybean (Glycine max (L.) Merril cv. M6410 IPRO), tomato (Solanum lycopersicum L. cv. Santa Cruz 'Kada') and mayze (Zea mays L. var. DKB 390), under greenhouse conditions for 30, 60 and 80 days, respectively. After the aforementioned periods, $H$. glycines inoculum was obtained by root processing in a blender. Next, the material was sieved on 850, 250 and 25 $\mathrm{mm}$ coupled sieves and washed in water; females retained in the $250 \mathrm{~mm}$ sieve were crushed and eggs were collected in the $25 \mathrm{~mm}$ sieve (methodology adapted from Dias-Arieira et al., 2003). Meloidogyne incognita inoculum was obtained from tomato plant roots, according to the methodology by Hussey and Barker (1973), adapted by Boneti and Ferraz (1981). On the other hand, roots were subjected to the extraction method described by Coolen and D'Herde (1972) to obtain P. brachyurus. The suspension obtained for all nematodes was calibrated at 500 nematodes (eggs, juveniles or adults)/ml, using Peters's slide and light microscope.

The study was conducted in a greenhouse located at latitude $23^{\circ} 30^{\prime} 51^{\prime \prime} \mathrm{S}$, longitude $51^{\circ} 25^{\prime} 10^{\prime \prime} \mathrm{W}$, and altitude $603.5 \mathrm{~m}$; it followed a completely randomized design, with five repetitions. Tagetes minutas seedlings (containing 3 to 4 leaves) from woody cuttings were individually transplanted into pots containing $3 \mathrm{~L}$ of substrate composed of soil and sand (1:3), which was previously autoclaved and characterized as dystroferric red Latosol. Next, the seedlings were individually inoculated with a suspension containing 1000, 2000 or 1000 eggs and/or juvenile or adult forms of $H$. glycines, $M$. incognita and $P$. brachyurus, respectively, in four open holes in the soil, around each seedling. Five (5) samples from each treatment were collected for nematode penetration evaluation purposes 5, 10 and 15 days after inoculation (DAI). Thus, the T. minuta root system inoculated with the aforementioned nematodes was separated from the shoot, carefully washed and subjected to the acid-fuchsin staining technique (Byrd Junior et al., 1983). Subsequently, temporary slides were prepared and assessed under light microscope in order to analyze the number of nematodes penetrating T. minuta roots.

Nematode reproduction in T. minuta was assessed in the $30^{\text {th }}, 60^{\text {th }}$ and $80^{\text {th }}$ DAI, whereas inoculum viability was just evaluated in the $30^{\text {th }}, 60^{\text {th }}$ and $80^{\text {th }}$ day after inoculation with $H$. glycines, M. incognita and P. brachyurus, respectively. Nematodes were extracted from the roots, according to the aforementioned methodologies, and evaluated for the number of $H$. glycines and $M$. incognita eggs + second stage juveniles (J2) or for the number of $P$. brachyurus eggs, juveniles and adults. The evaluations were performed using Peters's slide under light microscope. The herein obtained values were used to calculate the reproduction factor $(\mathrm{RF}=$ Final population/Initial population), according to Oostenbrink (1966). Fresh shoot and root weights were also evaluated in the current study. The data were assessed for variance normality (Shapiro Wilk test) and transformed through $\sqrt{(\mathrm{x}+0.5)}$, whenever necessary, and later compared through the Tukey test, at 5\% probability, in the Sisvar statistical software (Ferreira et al., 2011).

At the same time, nematode-infected T. minuta root systems were studied through histopathological sections in the $5^{\text {th }}, 10^{\text {th }}, 15^{\text {th }}, 30^{\text {th }}, 60^{\text {th }}$ and $80^{\text {th }}$ DAI. In order to do so, five plants from each treatment were collected; their shoots were discarded and their roots were washed in running water for later histological paraffin infiltration purposes. Root segments $(0.5-1.0 \mathrm{~cm})$ were sampled in the median and apical regions, and fixed in $70 \%$ FAA solution (formaldehyde + acetic acid $+70 \%$ alcohol) for 48 hours (Johansen, 1940). Then, they were dehydrated in alcohol series $(70,80,90$ and $100 \%$ ethanol) for 2 hours each, this procedure was followed by clarification in xylene + alcohol up to pure xylol. Subsequently, prefiltration with xylol + paraffin was carried out for 4 hours, and it was followed by infiltration in liquid paraffin for at least 24 hours. Two paraffin exchanges were performed, and the material was kept for approximately 1 hour in the oven, at $55^{\circ} \mathrm{C}$, at each exchange. The segments were placed in 
plastic molds contaning liquid paraffin; later, they were fixed in wood blocks using the paraffin itself and cross-sectioned ( $5 \mu \mathrm{m}$ thick) in a Leica 2155 rotating microtome.

The total of 1,520 histological sections were deposited on heated water + Gelita gelatin powder (adhesive) and, subsequently, placed on microscope slides. The sections were stained with $1 \%$ Toluidine Blue in acetate buffer, at pH 4.7, for 3 minutes (O'Brien et al., 1964), and arranged between slides and coverslips containing glycerin ( $0.5 \%)$ for evaluation purposes. Anatomical root assessments were performed under light microscope and all segments were photographed in a digital camera coupled to the microscope.

\section{Results}

The use of seeds in the T. minuta propagation study enabled $42.7 \%$ mean germination 30 days after sowing (data not shown). The woody segments showed $92 \%$ rooting of cuttings, which was higher than the rooting rate recorded for herbaceous segments (45\%) (Table 1). In addition, root diameter and length recorded for woody cuttings were higher than those recorded for the herbaceous ones (Table 1).

Table 1. Rooting rate, stem diameter of rooted cuttings and root length of woody and herbaceous cuttings of Tagetes minuta, after 30 cultivation days in greenhouse

\begin{tabular}{llll}
\hline Treatments & Rooting (\%) & Diameter of rooted cuttings (cm) & Root length (cm) \\
\hline Woody cuttings $(5$ to $6 \mathrm{~cm})$ & 92.0 & $0.45 \mathrm{a}$ & $5.30 \mathrm{a}$ \\
Herbaceous cuttings $(2.5$ to $3.5 \mathrm{~cm})$ & 45.0 & $0.11 \quad \mathrm{~b}$ & $1.89 \mathrm{~b}$ \\
$\mathrm{CV}(\%)$ & - & 5.04 & 3.75 \\
\hline
\end{tabular}

Note. Means followed by the same letter in the column did not differ from each other in the Tukey test, at $5 \%$ probability. $\mathrm{CV}=$ coefficient of variation.

The penetration of different nematodes in the T. minuta root system did not show statistical difference 5 DAI. However, $H$. glycines recorded higher penetration in the $10^{\text {th }}$ and $15^{\text {th }}$ DAI, whereas the other two species did not differ from each other (Table 2). In addition, H. glycines and P. brachyurus presented increasing penetration between the $5^{\text {th }}$ and $10^{\text {th }}$ DAI and between the $5^{\text {th }}$ and $15^{\text {th }}$ DAI, respectively, whereas $M$. incognita did not show penetration changes between the assessed periods.

Table 2. Number of Heterodera glycines, Meloidogyne incognita and Pratylenchus brachyurus penetrating Tagetes minuta root system 5, 10 and 15 days after inoculation (DAI)

\begin{tabular}{llll}
\hline Treatments & 5 DAI & 10 DAI & 15 DAI \\
\hline H. glycines & $3.5 \mathrm{aB}$ & $15.4 \mathrm{aA}$ & $9.8 \mathrm{aA}$ \\
M. incognita & $0.0 \mathrm{aA}$ & $0.4 \mathrm{bA}$ & $0.3 \mathrm{bA}$ \\
P. brachyurus & $1.1 \mathrm{aB}$ & $4,8 \mathrm{bA}$ & $2.6 \mathrm{bA}$ \\
\hline CV $(\%)$ & 38.1 & 147.1 & 44.3 \\
\hline
\end{tabular}

Note. Means followed by the same lowercase letter in the columns and by the same uppercase letter on the lines did not differ from each other in the Tukey test, at 5\% probability. Original data were processed through $\sqrt{(\mathrm{x}+0.5)}$.

Nevertheless, despite the increased $H$. glycines penetration, there was no development of sausage-like or female forms, i.e., all the nematodes remained as second stage juveniles; the same result was recorded for M. incognita (Figure 1). 

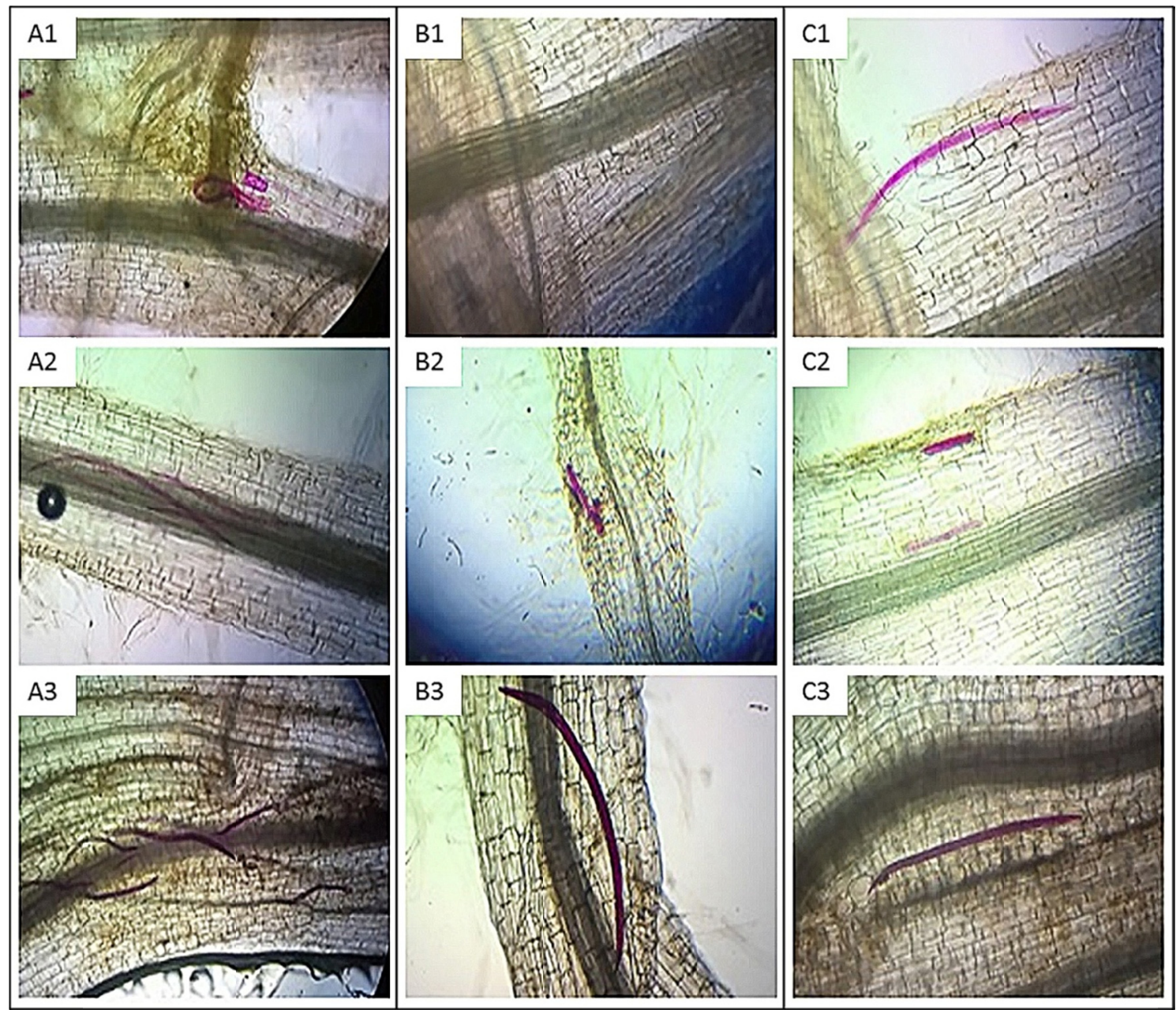

Figure 1. Heterodera glycines, Meloidogyne incognita and Pratylenchus brachyurus penetration in Tagetes minuta roots. A1, A2, A3: Penetration of H. glycines second-stage juveniles (J2) 5, 10 and 15 days after inoculation (DAI), respectively. B1, B2, B3: Penetration of $M$. incognita J2, 5, 10 and 15 DAI, respectively. C1, C2, C3: Penetration of $P$. brachyurus, 5, 10 and 15 DAI, respectively

According to the parasitism study, the viability of $H$. glycines, M. incognita and P. brachyurus inocula was confirmed through the reproduction observed in soybean, tomato and maize plants, with RF equal to 25.9, 53.7 and 12.3 at the $30^{\text {th }}, 60^{\text {th }}$ and $80^{\text {th }}$ DAI, respectively.

Similar to what was observed for nematode penetration, the total number of $H$. glycines eggs $+\mathrm{J} 2$ presented continuous increase in the assessments performed in the $30^{\text {th }}, 60^{\text {th }}$ and $80^{\text {th }} \mathrm{DAI}$, although it did not show statistical difference in the last two assessed periods (Table 3). On the other hand, M. incognita did not present difference between assessed periods, whereas the number of eggs $+\mathrm{J} 2$ was lower than that recorded for $\mathrm{H}$. glycines in all assessments. Although P. brachyurus reproduction did not differ between assessed periods, the species presented the largest number of nematodes per T. minuta root system; it was statistically different from M. incognita, but equal to $H$. glycines (Table 3 ). The data recorded for the number of nematodes per root gram followed the same trend as the total number of nematodes (Table 3). 
Table 3. Total number of nematodes (eggs and juveniles) of Heterodera glycines, Meloidogyne incognita and Pratylenchus brachyurus, and nematodes per root gram, in Tagetes minuta roots 30, 60 and 80 days after nematode inoculation (DAI) in greenhouse

\begin{tabular}{|c|c|c|c|}
\hline \multirow{2}{*}{ Treatment } & \multicolumn{3}{|c|}{ Total number of nematodes } \\
\hline & 30 DAI & 60 DAI & 80 DAI \\
\hline H. glycines & $160 \mathrm{abB}$ & $240 \mathrm{abA}$ & $336 \mathrm{abA}$ \\
\hline M. incognita & $32 \mathrm{bA}$ & $16 \mathrm{bA}$ & $48 \mathrm{bA}$ \\
\hline P. brachyurus & $432 \mathrm{aA}$ & $960 \mathrm{aA}$ & $800 \mathrm{aA}$ \\
\hline \multirow[t]{2}{*}{$\mathrm{CV}(\%)$} & \multicolumn{3}{|c|}{39.32} \\
\hline & \multicolumn{3}{|c|}{ Nematode/g root } \\
\hline H. glycines & $107 \mathrm{abB}$ & $232 \mathrm{abA}$ & $352 \mathrm{abA}$ \\
\hline M. incognita & $20 \mathrm{bA}$ & $9 \mathrm{bA}$ & $36 \mathrm{bA}$ \\
\hline P. brachyurus & $505 \mathrm{aA}$ & $1160 \mathrm{aA}$ & $793 \mathrm{aAB}$ \\
\hline $\mathrm{CV}(\%)$ & & 41.32 & \\
\hline
\end{tabular}

Note. Means followed by the same lowercase letter in the columns and by the same uppercase letters on the lines did not differ from each other in the Tukey test, at 5\% probability. Original data were processed through $\sqrt{(x+0.5)}$.

The reproduction factor of $H$. glycines was lower than one in all three assessed periods; the highest value (0.34) was recordedin the $80^{\text {th }}$ DAI (Table 4). Tagetes minuta showed RF value 0.16 at the $30^{\text {th }}$ DAI, whereas the soybean plant (control) showed $\mathrm{RF}=25.9$. Meloidogyne incognita was the nematode presenting the lowest RF, with values equal to or lower than 0.02 ; the nematode showed RF value 0.02 in T. minuta and 53.7 in the susceptible tomato (control), at the $60^{\text {th }}$ DAI. Pratylenchus brachyurus presented RF close to one in T. minuta at the $60^{\text {th }}$ and $80^{\text {th }}$ DAI, 0.96 and 0.80 , respectively (Table 4). However, it is worth highlighting that the mayze used as control to assess the nematode inoculum viability showed $\mathrm{RF}=12.3$ at the $80^{\text {th }} \mathrm{DAI}$.

Table 4. Reproduction factor (RF) of Heterodera glycines, Meloidogyne incognita and Pratylenchus brachyurus in Tagetes minuta 30, 60 and 80 days after inoculation (DAI)

\begin{tabular}{llll}
\hline \multirow{2}{*}{ Treatments } & \multicolumn{3}{c}{ Reproduction Factor } \\
\cline { 2 - 4 } & 30 DAI & 60 DAI & 80 DAI \\
\hline H. glycines & 0.16 & 0.24 & 0.34 \\
M. incognita & 0.01 & 0.02 & 0.02 \\
P. brachyurus & 0.43 & 0.96 & 0.80 \\
\hline
\end{tabular}

Note. $\mathrm{RF}=$ Final population/Initial population, considered resistant when RF $<1$ (Oostenbrink, 1966).

Tagetes minuta plants inoculated with $H$. glycines showed lower fresh root weight than the control plants at the $60^{\text {th }}$ and $80^{\text {th }}$ DAI. In addition, they showed gradual fresh root weight decrease at the $60^{\text {th }}$ and $80^{\text {th }}$ DAI in comparison to the $30^{\text {th }}$ DAI (Table 5). On the other hand, plants inoculated with $M$. incognita did not differ from the nematode-free control. Pratylenchus brachyurus, in its turn, caused a reduction in root weight in the three assessed periods, in comparison to the control. The analysis applied to the periods when each of the two last nematodes were assessed did not show root weight change (Table 5). All nematode treatments reduced the fresh shoot weight in plants assessed in the $60^{\text {th }}$ and $80^{\text {th }}$ DAI; only the control showed fresh shoot weight increase when the results in the assessments performed in the $30^{\text {th }}$ and $60^{\text {th }}$ inoculation days were compared to each other (Table 5). 
Table 5. Fresh shoot weight of Tagetes minuta plants 30, 60 and 80 days after inoculation (DAI) with Meloidogyne incognita, Pratylenchus brachyurus and Heterodera glycines, grown under greenhouse conditions. Londrina, PR, 2016

\begin{tabular}{|c|c|c|c|}
\hline \multirow{2}{*}{ Treatment } & \multicolumn{3}{|c|}{ Fresh root weight (g) } \\
\hline & 30 DAI & 60 DAI & 80 DAI \\
\hline No inoculation & $2.21 \mathrm{aA}$ & $2.08 \mathrm{aA}$ & $2.58 \mathrm{aA}$ \\
\hline H. glycines & $1.65 \mathrm{abA}$ & $1.11 \mathrm{bAB}$ & $0.96 \mathrm{bB}$ \\
\hline M. incognita & $1.89 \mathrm{abA}$ & $1.86 \mathrm{abA}$ & $1.49 \mathrm{abA}$ \\
\hline P. brachyurus & $1.18 \mathrm{bA}$ & $0.93 \mathrm{bA}$ & $1.01 \mathrm{bA}$ \\
\hline \multirow[t]{2}{*}{$\mathrm{CV}(\%)$} & 27.67 & & \\
\hline & \multicolumn{3}{|c|}{ Fresh shoot weight (g) } \\
\hline No inoculation & $3.29 \mathrm{aAB}$ & $4.03 \mathrm{aA}$ & $3.60 \mathrm{aB}$ \\
\hline H. glycines & $2.39 \mathrm{abA}$ & $1.82 \mathrm{bA}$ & $1.58 \mathrm{bA}$ \\
\hline M. incognita & $2.16 \mathrm{bA}$ & $2.60 \mathrm{bA}$ & $1.92 \mathrm{bA}$ \\
\hline P. brachyurus & $1.21 \mathrm{cA}$ & $1.73 \mathrm{bA}$ & $1.47 \mathrm{bA}$ \\
\hline $\mathrm{CV}(\%)$ & 24.72 & & \\
\hline
\end{tabular}

Note. Means followed by the same lowercase letter in the column and by the same uppercase letter on the line did not differ from each other in the Tukey test, at 5\% probability level.

The analysis applied to the histological sections showed that, despite the nematode penetration in the roots, plants parasitized by $H$. glycines, $M$. incognita and $P$. brachyurus did not show visible morphological differences in their cells (Figure 2). However, cortical lesions were observed in roots parasitized by $P$. brachyurusin the $80^{\text {th }}$ DAI (Figure 2, D6). 


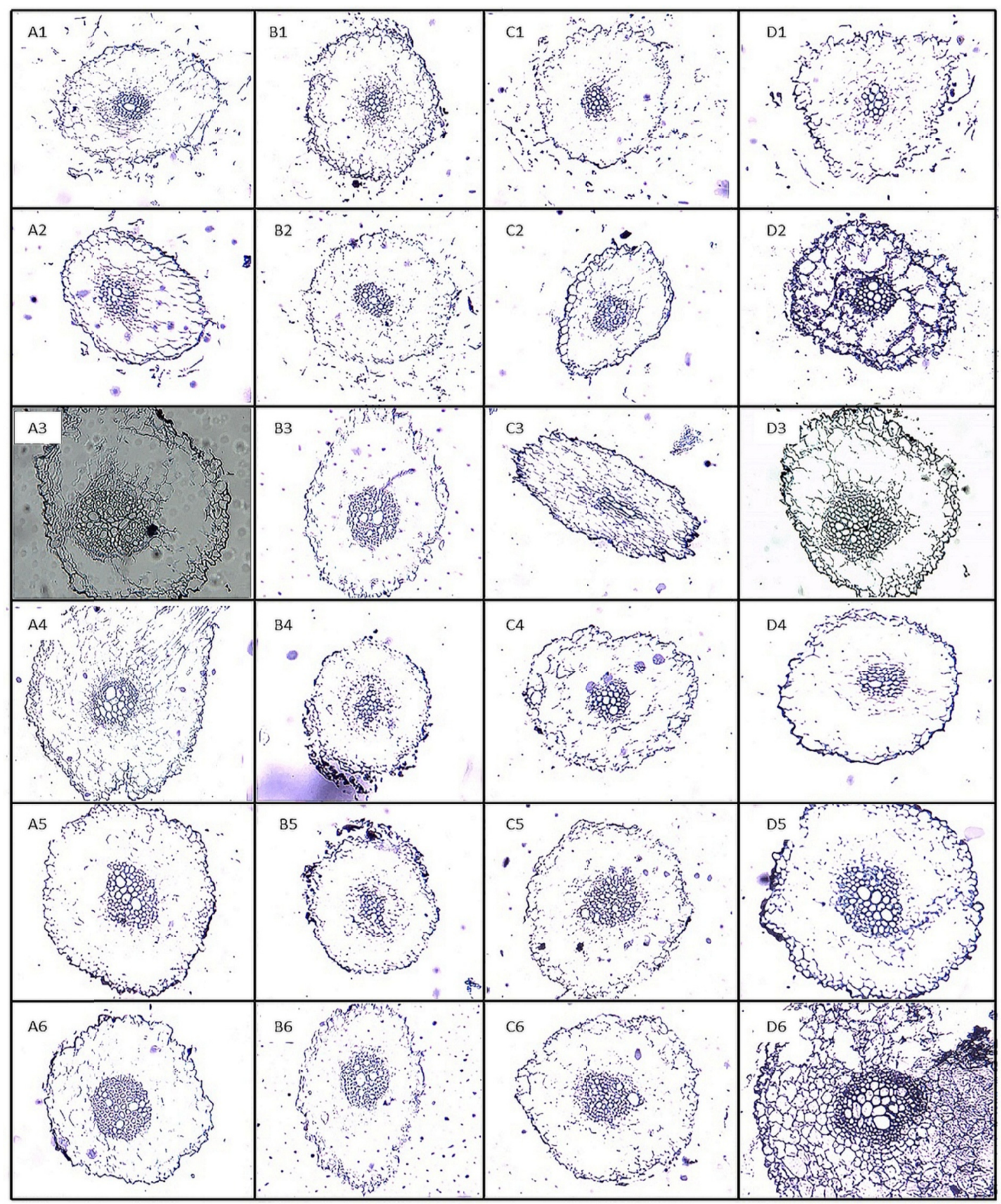

Figure 2. Histological cross-sections of Tagetes minuta roots, 5, 10, 15, 30, 60 and 80 days after inoculation. A1-A6) Roots without nematode inoculation; B1-B6) Roots inoculated with Hetedora glycines; C1-C6) Roots inoculated with Meloidogyne incognita; D1-D6) Roots inoculated with Pratylenchus brachyurus

\section{Discussion}

The identification of antagonistic plants presenting nematode control potential is one of the main alternatives for the sustainable management of these parasites. However, many plants presenting nematode control potential have not been genetically improved and may show growth, flowering and seed production variations. As for the current case, T. minuta, which is a weed species, presented staggered germination, fact that assured greater survival rates in the environment, although it made it difficult to obtain plant uniformity for experimental use purposes. However, 
the seed germination rate $(47 \%)$ was in compliance with other scientific observations recorded for the genus; it varies from 34 to $57 \%$ in T. minuta, depending onthe temperature and light conditions (Felippe \& Pollo, 1983; Ferreira et al., 2001). The cuttings, mainly the woody, present greater nutritional reserve; thus, they are more likely to form new plants. In addition, this reserve may affect the rooting process, since the greater the availability of nutrients, the better the asexual propagation performance of these plants (Nicoloso et al., 1999).

The effectiveness of plants belonging to genus Tagetes in reducing nematode populations has been proven over the years (Ploeg, 2000; Buena et al., 2008; Marahatta et al., 2010; Marahatta et al., 2012). The way these plants act on nematodes is variable; one of the most cited ways lies on the production of toxic substances belonging to the thienyl group. These substances show nematicidal potential (Gommers \& Bakker, 1988; Kyo et al., 1990) and properties that appear to be activated during nematode penetration and movement in the cortex, fact that triggers a series of cascade reactions (Gommers \& Bakker, 1988). However, these substances may also be released by the roots (Arroo et al., 1995) and T. minuta root exudates inhibited nematode hatching (Siddiqui \& Alam, 1988), whereas T. patula root extracts enabled 68\% mobility of $M$. incognita juveniles in vitro (Franzener et al., 2007). Nevertheless, nematodes' sensitivity to different substances produced by Tagetes may vary (Arroo et al., 1995).

Some antagonistic plants allow many nematodes to penetrate their roots, sometimes in larger amounts than those observed in susceptible plants; however, these nematodes are not able to complete their life cycle. An example of it was observed in relations involving java (Macrotyloma axillare (E. Mey.) Verdc. cv. Java) and M. javanica (Miamoto et al., 2016), crotalaria species and Meloidogyne spp. (Silva et al., 1990), and velvet bean, pigeon pea and H. glycines (Valle et al., 1997). However, it was possibly not the mode of action plants adopted in the present study, mainly with respect to $M$. incognita, since it showed low penetration rate.

The expression of multiple modes of action appears to be common in plants' antagonism to nematodes (Chitwood, 2002; Wang et al., 2002); consequently, such expression is widely discussed in relations involving Tagetes spp., which may act on nematodes as trap crop, non-host, poor-host or through allelopathy (Hooks et al., 2010). Thus, the $T$. minuta specimen investigated in the present study seemed to have been less attractive to nematodes, mainly to the root-knot nematode, or to have released toxic substances with the potential to mimic the rhizosphere or even to perform nematicidal activity. The low nematode penetration in Tagetes roots was previously evidenced and attributed to substance-release by the roots (Caswell et al., 1991). In addition, the sedentary endoparasite nematodes that eventually penetrated the roots failed to develop beyond second stage juveniles, thus corroborating results recorded in previous studies (Rangaswamy et al., 1993; Ploeg \& Maris, 1999). Thus, it is possible assuming that there was no feeding site formation or that it presented malfunction; the first hypothesis is the most likely due to lack of morphological changes in the root system.

Tagetes minuta may have adopted a different mode of action on the migrating endoparasite $P$. brachyurus, since the nematode presented low penetration, sometimes lower than that recorded for H. glycines, although it showed reproduction factor close to one. This result leads to the hypothesis that the nematode could, even if inefficiently, reproduce inside the root tissue and that, in this case, the plant could be considered a poor host to the nematode (Hooks et al., 2010). This hypothesis is corroborated by lesions found in the cortex cells in the $80^{\text {th }}$ day after inoculation, fact that evidenced the movement and, possibly, the feeding activity of the nematode in cortical parenchyma cells.

It is worth highlighting that different Tagetes species and cultivars may present varying reactions to different nematodes (Buena et al., 2008; Marahatta et al., 2010), as well as that control effectiveness depends on climate conditions and on cultivation type (Ploeg \& Maris, 1999; Ploeg, 2000).

$\mathrm{n}$ this way, we conclude that Heterodera glycines and Meloidogyne javanica presented low reproduction factor in Tagetes minuta; Heterodera glycines recorded the highest penetration rate. Pratylenchus brachyurus presented reproduction factor close to, but lower than, one and much lower than that recorded for the control plant. Histological studies presented cortical lesions in T. minuta parasitized with P. brachyurus but did not show visible morphological differences to $H$. glycines and $M$. incognita parasitism.

\section{References}

Adekunle, O. K., Acharya, R., \& Singh, B. (2007). Toxicity of pure compounds isolated from Tagetes minuta oil to Meloidogyne incognita. Australasian Plant Disease Notes, 2, 101-104. https://doi.org/10.1071/DN07042

Arroo, R. R. J., De Brouwer, A. P. M., Croes, A. F., \& Wullems, G. J. (1995). Thiophene inter conversion in elicitor-treated roots of Tagetes patula L. Plant Cell Report, 15, 133-137. https://doi.org/10.1007/BF0169 0270 
Boneti, J. I. S., \& Ferraz, S. (1981). Modificação do método de Hussey e Barker para extração de ovos de Meloidogyne exigua de raízes de cafeeiro. Fitopatologia Brasileira, 6, 553.

Buena, A. P., Diez-Rojo, M. A., Lopez-Perez, J. A., Robertson, L., Escuer, M., \& Bello, A. (2008). Screening of Tagetes patula L. on different populations of Meloidogyne. Crop Protection, 27, 96-100. https://doi.org/ 10.1016/j.cropro.2007.04.011

Byrd Junior, D. W., Kirpatrick, T., \& Barker, K. R. (1983). An improved technique for clearing and staining plant tissues for detection of nematodes. Journal of Nematology, 15, 142-143.

Caswell, E. P., De Frank, J., Apt, W. J., \& Tang, C. S. (1991). Influence of nonhost plants on population decline of Rotylenchulus reniformis. Journal of Nematology, 23, 91-98.

Chamorro, E. R., Ballerini, G., Sequeira, A. F., \& Velasco, G. (2008). Chemical composition of essential oil from Tagetes minuta L. leaves and flowers. The Journal of Argentine Chemichal Society, 96, 80-86.

Chitwood, D. J. (2002). Phytochemical based strategies for nematode control. Annual Review of Phytopathology, 40, 221-249. https://10.1146/annurev.phyto.40.032602.130045

Coolen, W. A., \& D'Herde, C. J. (1972). A method for the quantitative extraction of nematodes from plant tissue. State Agriculture Research. Center, Ghent.

Dias-Arieira, C. R., Ferraz, S., Freitas, L. G., \& Mizobutsi, E. H. (2003). Avaliação de gramíneas forrageiras para o controle de Meloidogyne incognita e M. javanica (Nematoda). Acta Scientiarum, 25, 473-477.

Felippe, G. M., \& Pollo, M. (1983). Germinação de ervas invasoras: Efeito de luz e escarificação. Revista Brasileira de Botânica, 6, 55-60.

Ferreira, D. F. (2011). Sisvar: A computer statistical analysis system. Ciência e Agrotecnologia, 35, 1039-1042. https://doi.org/10.1590/S1413-70542011000600001

Ferreira, A. G., Cassol, B., Rosa, S. G. T., Silveira, T. S., Stival, A. L., \& Silva, A. A. (2001). Germinacão de sementes de Asteraceae nativas no Rio Grande do Sul, Brasil. Acta Botanica Brasilica, 15, 231-242. https://doi.org/10.1590/S0102-33062001000200009

Franzener, G., Martinez-Franzener, A. S., Stangarlin, J. R., Furlanetto, C., \& Schwan-Estrada, K. R. F. (2007). Protection of tomato plants by Tagetes patula aqueous extract against Meloidogyne incognita. Nematologia Brasileira, 31, 27-36.

Furtado, R. F., Lima, M. G. A., \& Neto, M. A. (2005). Atividade larvicida de óleos essenciais contra Aedes aegypti L. (Diptera: Culicidae). Neotropical Entomology, 34, 843-847. https://doi.org/10.1590/S1519-566X 2005000500018

García, A. A., \& Carril, E. P. U. (2009). Metabolismo secundário de plantas. Reduca. Serie Fisiología Vegetal, 2, 119-145.

Gommers, F. J., \& Bakker, J. (1988). Physiological changes induced by plant responses or products. In G. O. Poinar Jr., \& H. B. Jansson (Eds.), Diseases of Nematodes (pp. 46-49). Boca Raton, FL, CRC Press Inc.

Hooks, C. R. R., Wang, K. H., Ploeg, A., \& McSorley, R. (2010). Using marigold (Tagetes spp.) as a cover crop to protect crops from plant-parasitic nematodes. Applied Soil Ecology, 46, 307-320. https://doi.org/10.1016/ j.apsoil.2010.09.005

Hussey, R. S., \& Barker, K. R. (1973). A comparison of methods of collecting inocula of Meloidogyne spp., including a new technique. Plant Disease Report, 57, 1025-1028.

Johansen, D. A. (1940). Plant Michrotechnique (p. 523). New York, McGraw-Hill Book.

Kyo, M., Miyauchi, Y., Fujimoto, T., \& Mayama, S. (1990). Production of nematicidal compounds by hairy root cultures of Tagetes patula L. Plant Cell Report, 9, 393-397. https://doi.org/10.1007/BF00232407

Marahatta, S. P., Wang, K. H., Sipes, B. S., \& Hooks, C. R. R. (2010). Strip-till cover cropping for managing nematodes, soil mesoarthropods and weeds in a bitter melon agroecosystem. Journal of Nematology, 42, 111-119.

Marahatta, S. P., Wang, K. H., Sipes, B. S., \& Hooks, C. R. R. (2012). Effects of Tagetes patula on active and inactive stages of root-knot nematodes. Journal of Nematology, 44, 26-30. 
Miamoto, A., Dias-Arieira, C. R., Cardoso, M. R., \& Puerari, H. H. (2016). Penetration and reproduction of Meloidogyne javanica on leguminous crops. Journal of Phytopathology, 164, 890-895. https://doi.org/ 10.1111/jph.12508

Moreira, F. J. C., \& Ferreira, A. C. S. (2015). Controle alternativo de nematoide das galhas (Meloidogyne enterolobii) com cravo de defunto (Tagetes patula L.), incorporado ao solo. Holos, 31, 99-110. https://doi.org/10.15628/holos.2015.1600

Naqinzhad, A., \& Mehrvarz, S. S. (2007). Some new records for Iran and flora Iranica area collected from Boujagh National Park, N. Iran. Iranian Journal Botany, 13, 112-119.

Natarajan, N., Cork, A., Boomathi, N., Pandi, R., Velavan, S., \& Dhakshnamoorthy, G. (2006). Cold aqueous extracts of African marigold, Tagetes erecta for control tomato root knot nematode, Meloidogyne incognita. Crop Protection, 25, 1210-1213. https://doi.org/10.1016/j.cropro.2006.03.008

Nicoloso, F. T., Fortunato, R. P., \& Fogaça, M. A. F. (1999). Influência da posição da estaca no ramo sobre o enraizamento de Pfaffia glomerata (Spreng.) Pedersen em dois substratos. Ciência Rural, 29, 277-283. https://doi.org/10.1590/S0103-84781999000200015

Obongoya, B. O., Wagai, S. O., \& Odhiambo, G. (2010). Phytotoxic effect of selected crude plant extracts on soil-borne fungi of common bean. African Crop Science Journal, 18, 15-22. https://doi.org/10.4314/acsj. v18i1.54189

O'Brien, T. P., Feder, N., \& McCully, M. E. (1964). Polychoromatic staining of plant cell walls by toluidine blue. Protoplasma, 59, 368-373. https://doi.org/10.1007/BF01248568

Oostenbrink, M. (1966). Major characteristics of the relation between nematodes and plants. Mendelingen Landbouwhogeschool, 66, 1-46.

Ploeg, A. T., \& Maris, P. C. (1999). Effect of temperature on suppression of Meloidogyne incognita by Tagetes cultivars. Journal of Nematology, 31, 709-714.

Ploeg, A. T. (2000). Effects of amending soil with Tagetes patula cv. Single Gold on Meloidogyne incognita infestation of tomato. Nematology, 2, 489-493. https://10.1163/156854100509394

Rangaswamy, S. D., Reddy, P. P., \& Joshi, S. (1993). Histopathological and histochemical investigations on antagonistic trap crops (marigold and mustard) and susceptible tomato infested with Meloidogyne incognita. Current of Nematology, 4, 203-206.

Sadia, S., Khalid, S., Qureshi, R., \& Bajwa, A. A. (2013). Tagetes minuta, a useful underutilized plant of family Asteraceae: A review. Pakistan Journal of Weed Science Research, 19, 179-189.

Siddiqui, M. A., \& Alam, M. M. (1988). Studies on the nematotoxicity of root exudates of certain species of Tagetes. Indian Journal of Nematology, 18, 335-337.

Silva, G. S., Ferraz, S., \& Santos, J. M. (1990). Histopatologia de raízes de Crotalaria parasitadas por Meloidogyne javanica. Fitopatologia Brasileira, 15, 46-48.

Soule, J. A. (1996). Novel annual and perennial Tagetes. In J. Janick (Ed.), Progress in New Crops (pp. 546-551). Arlington, VA, ASHS Press.

Tomova, B., S., Waterhouse, J. S., \& Doberski, J. (2005). The effect of fractionated Tagetes oil volatiles on aphid reproduction. Entomologia Experimentalis et Applicata, 115, 153-159. https://doi.org/10.1111/j.1570-7458. 2005.00291.x

Valle, L. A. C., Ferraz, S., \& Teixeira, D. A. (1997). Estímulo a eclosão de juvenis, penetração e desenvolvimento de Heterodera glycines em raízes de mucuna preta (Mucuna aterrima) e feijão guandu (Cajanus cajan). Nematologia Brasileira, 21, 67-83.

Wang, K. H., Sipes, B. S., \& Schmitt, D. P. (2002). Crotalaria as a cover crop for nematode management. Nematropica, 32, 35-57.

\section{Copyrights}

Copyright for this article is retained by the author(s), with first publication rights granted to the journal.

This is an open-access article distributed under the terms and conditions of the Creative Commons Attribution license (http://creativecommons.org/licenses/by/4.0/). 